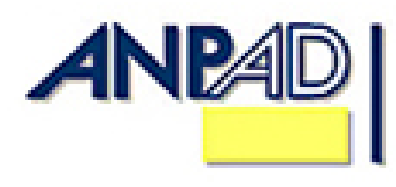

Available online at

http://www.anpad.org.br/bar

BAR, Rio de Janeiro, v. 10, n. 3, art. 6, pp. 347-369, July/Sept. 2013

\title{
Determinants of the Capital Structure of Small and Medium Sized Brazilian Enterprises
}

Denis Forte

E-mail address: denisfortebr@yahoo.com.br

Universidade Presbiteriana Mackenzie - CCSA/UPM Av. Angélica, 736, apto. 62, Santa Cecilia, 01228-000, São Paulo, SP, Brazil.

Lucas Ayres Barros E-mail address: lucasayres@usp.br Universidade de São Paulo - FEA/USP Rua Alves Guimarães, 1133, apto. 62, Pinheiros, 05410-002, São Paulo, SP, Brazil.

Wilson Toshiro Nakamura E-mail address: wtnakamura@uol.com.br Universidade Presbiteriana Mackenzie - CCSA/UPM Rua Correia de Lemos, 390, apto. 62, 04140-000, São Paulo, SP, Brazil.

Received 8 June 2012; received in revised form 21 February 2013 (this paper has been with the authors for two revisions); accepted 4 March 2013; published online $1^{\text {st }}$ July 2013.

Editor's note. Ricardo Pereira Câmara Leal served as Associate Editor for this article. 


\begin{abstract}
This research investigates the determinants of the capital structure of small and medium enterprises (SMEs) using a unique database that includes over 19,000 Brazilian firms and spans 13 years of data. The econometric analysis employs the System Generalized Method of Moments estimator (GMM-Sys) and two strong results emerge: (a) profitability is negatively related to leverage, and (b) asset growth is positively related to leverage. Both results are consistent with the pecking order theory of capital structure and suggest that SMEs tend to finance their expansion with debt only after exhausting their internal resources. Additionally, we find weaker evidence for the following: (a) size is positively related to leverage, which can be interpreted as evidence that larger firms have more access to credit markets; (b) riskier SMEs tend to be less financially leveraged, consistent with the bankruptcy cost arguments from trade-off theories; and (c) the age of the firm is negatively related to financial leverage, suggesting that older SMEs may be slightly more conservative in their financing choices. Finally, the magnitude of the coefficient of lagged leverage shows the high persistence of this variable and is compatible with the hypothesis that SMEs adjust their debt/equity ratio towards a target value, although at a low speed.
\end{abstract}

Key words: small and medium enterprises (SMEs); capital structure; leverage; corporate finance. 


\section{Introduction}

For the most part, the empirical capital structure literature investigates the behavior of stock market-listed companies to test the extent to which capital structure theories explain the cross-section of financing decisions. Therefore, these studies ignore the peculiarities of private small and medium enterprises (SMEs), which represent the majority of firms and account for the largest part of the gross domestic product (GDP) and employment of most countries. To address this gap we use a unique database provided by Serasa Experian that includes over 19,000 SMEs, representing a variety of business segments based in the state of Sao Paulo, a state that accounts for approximately $40 \%$ of the Brazil's GDP. We collected several financial indicators for these firms from 1994 through 2006. Though many firms had incomplete data, after removing the potential outliers, we were able to use more firm-year observations than most previous empirical corporate finance studies that use either SMEs or listed companies.

This research contributes to the capital structure literature in the following ways. First, we review the still incipient and fragmented literature that focuses on the capital structure decisions of SMEs in several countries and find two main research approaches: one based on questionnaires, surveys and interviews and another that uses secondary databases. Two tables show the variables, methods and results of these efforts in chronological order. Second, to our knowledge, we perform the largest empirical investigation of the determinants of the capital structure of privately owned SMEs in an emerging market and one of the largest investigations in the world, using a unique panel dataset to examine the cross-sectional and time-series variation in the leverage ratios of SMEs. Third, we estimate the empirical models by employing an econometric procedure that is more sophisticated than those used in most previous SME research - the System Generalized Method of Moments estimator (GMM-Sys) dynamic panel estimator (Blundell \& Bond, 1998). The GMM-Sys procedure allows us to explore the panel structure of our dataset to address important and frequently ignored methodological concerns that are common to corporate finance studies, such as dynamic endogeneity (see Wintoki, Linck, \& Netter, 2012).

The empirical analysis strongly suggests that the more profitable firms tend to be less financially levered. The estimated coefficients for our profitability proxies are both statistically and economically significant, which is compatible with pecking order arguments; i.e., when deciding how to finance their activities, firms favor internally generated resources over outside capital, either debt or equity. Additionally, we find that after controlling for profitability and other firm characteristics, asset growth is positively related to debt financing, implying that SMEs tend to finance their expansion with debt when internally generated funds are insufficient, which again is compatible with the pecking order theory. Additionally, we find weaker evidence that larger firms have more debt capacity, as predicted by traditional capital structure theories and that older SMEs are more conservative and tend to use less debt, although the magnitude of the coefficient is small in both cases. Finally, in some regressions, the coefficient for our risk proxy (rolling five-year standard deviation of the profitability ratio) is negative and statistically significant, as predicted by traditional trade-off theories.

The panel structure of our data also allows us to examine the dynamic behavior of leverage ratios. We find that leverage is highly persistent and that lagged leverage is the best predictor of subsequent leverage, consistent with the extant empirical literature. Interpreting our estimates in the context of partial adjustment models (see Oztekin \& Flannery, 2012), we find annual speed of adjustment coefficients ranging from $20.4 \%$ to $34.1 \%$. These estimates suggest that SMEs may periodically adjust their leverage ratios towards their target (or optimal) leverage but do so at a low speed. Recent empirical studies report similar results (Aybar-Arias, Casino-Martinez, \& Lopez-Gracia, 2012; Oztekin \& Flannery, 2012).

The remainder of the paper is organized as follows: second section reviews the literature on capital structure theories and their application to small and medium enterprises (SMEs); third section 
describes the data and the empirical strategy; fourth section presents the results; and final section concludes the paper.

\section{Literature Review - Capital Structure and SMEs}

Since the 1950s, capital structure has developed into one of the most productive and controversial research areas in the field of corporate finance, spawning a multitude of theoretical and empirical studies. Modigliani and Miller (1958) set the stage for subsequent research by proposing that financing choices are irrelevant in perfect markets. Later theoretical contributions argued that in a more realistic setting, firms could maximize market value by using the tax benefits associated with debt financing before excessively increasing their expected bankruptcy costs. The related theories that focus on the various costs and benefits of debt and equity financing became known as trade-off approaches (Harris \& Raviv, 1991).

Jensen and Meckling (1976) reinterpreted the capital structure decision puzzle by considering that employees are hired to pursue the objectives of the owners of the firm, but they are actually biased towards the preservation of their own interests. Since then, a behavioral component known as agency cost was introduced in the capital structure equation. This conflict of interest problem was reinforced by Leland and Pyle (1977), who unveiled the information asymmetries between managers and investors in the process of valuing companies. Myers and Majluf (1984) later advanced a related theory, known as the pecking order theory, stating that information asymmetries would lead firms to always prefer to finance their activities with internally generated funds, followed by debt issuance, and would choose to issue new equity only as a last resort.

More recently, Baker and Wurgler (2002) proposed a theory founded in the exploitation of capital market inefficiencies by firm managers, in which a company would tend to issue new shares whenever the difference between its accounting value and its market value became sufficiently favorable. This third major line of capital structure research was called Equity Market Timing.

The empirical research in this field has also been vast and diverse. In a seminal paper, Titman and Wessels (1988) used firm-level accounting and market data to find that asset structure, non-debt tax shields, growth, singularity, industrial classification, size, profit volatility and profitability were potential determinants of U.S. companies' financing decisions. Later studies addressed other empirical issues, such as the dynamic behavior of leverage ratios, using panel data and more sophisticated estimation procedures. For example, Ozkan (2001) and Gaud, Jani, Hoesli and Bender (2005) suggested that listed companies partially adjust their leverage ratios towards a target (supposedly optimal or value-maximizing) ratio, as predicted by the trade-off approaches.

Notwithstanding the diversity of the capital structure literature, relatively few authors have investigated the financing decisions of small and medium enterprises. One possible reason for this limitation is that SME data are often scarce and sometimes unreliable because these firms, which are typically privately owned, are not required to disclose detailed information or have their reports audited. In addition, it has often been assumed that privately owned SMEs will eventually become publicly traded companies, though relatively few firms list their shares on a stock exchange or issue any publicly traded security throughout their life cycle.

Small and medium enterprises are responsible for a significant portion of the economic growth and employment in most countries. Because of the specificities and the life cycle of SMEs, they tend to be privately held and to employ less sophisticated accounting and financial practices than their larger counterparts. In fact, Katz and Cabezuelo (as cited in Gartner, Shaver, Carter, \& Reynolds, 2004) report that many start-up companies have financial problems such as inadequate capitalization, excessive debt, and poor record keeping, and they relate these common problems to the poor financial education of entrepreneurs and, consequently, of the company. 
Because of this data scarcity, investigators have often resorted to qualitative research designs. In a few cases, however, SME databases have been made available by official or private data providers, allowing researchers to perform statistical analyses using large samples. One example of the latter approach is the work by Kremp, Sauvé and Paranque (1999), which was part of a joint project between Deutsche Bundesbank and the Banque de France to describe the asset and liability structure of manufacturing firms incorporated in Germany and France and investigate the monetary transmission mechanisms in the European Monetary Union. The authors constructed balanced panels with 15,000 French firms and over 9,000 German firms observed between 1987 and 1996 and between 1987 and 1995, respectively.

In the following tables, we briefly describe selected empirical works in this still incipient field, presented in chronological order. The studies that used secondary data are described in Table 1. Table 2 presents the studies that gathered primary data (via questionnaires, surveys and interviews).

Table 1

SME Capital Structure Studies Using Secondary Panel Data

\begin{tabular}{lll}
\hline Authors, Year & Database, Period & Main Results \\
\hline $\begin{array}{l}\text { Kremp, Sauvé and } \\
\text { Paranque (1999) }\end{array}$ & $\begin{array}{l}\text { 15,000 SMEs in France (1987-95) and } \\
9,000 \text { in Germany (1987-96) }\end{array}$ & $\begin{array}{l}\text { Firm growth has a positive impact on } \\
\text { borrowing, whereas the negative } \\
\text { correlation of profit and debt supports } \\
\text { the pecking order theory. The cost of } \\
\text { finance and debt are negatively } \\
\text { correlated, with greater impact in larger } \\
\text { companies than in SMEs. }\end{array}$ \\
& &
\end{tabular}

Michaelas, Chittenden and 3,500 SMEs in the UK (1986-1995) Poutziouris (1999)

Benito (2003)

Cassar and Holmes (2003) 1,555 SMEs in Australia (1995-1998)

Sanchez-Vidal and Martin- 1,566 SMEs in Spain (1994- 2000) Ugedo (2005)

Trovato and Alfó (2006) 1,900 SMEs in Italy (1989-1994)
6,417 SMEs in Spain (1985-2000) and 1,784 in the UK (1973 -2000)

$$
\text { Are }
$$

\section{are} , and the results are consistent with static trade-off and pecking order models.

Pecking order theory holds for the small- and medium-sized enterprises and for the high-growth and highly leveraged companies.

Subsidized firms have more capitalintensive investments. Risk is significantly negative against leverage, but profitability is not significant. 
Table 1 (continued)

\begin{tabular}{|c|c|c|}
\hline Authors, Year & Database, Period & Main Results \\
\hline Abor (2007) & $\begin{array}{l}160 \text { SMEs in Ghana and } 200 \text { in South } \\
\text { Africa (1998-2003) }\end{array}$ & $\begin{array}{l}\text { Conclusions showed a negative } \\
\text { relationship between long-term debt } \\
\text { and firm performance. }\end{array}$ \\
\hline $\begin{array}{l}\text { López-Gracia and Sogorb- } \\
\text { Mira (2008) }\end{array}$ & 3,569 SMEs in Spain (1995- 2004) & $\begin{array}{l}\text { Results are consistent with pecking } \\
\text { order predictions but also suggest that } \\
\text { firms seek optimum leverage (as in a } \\
\text { trade-off behavior). Financing choices } \\
\text { appear to be somewhat different } \\
\text { between SMEs and larger companies. }\end{array}$ \\
\hline $\begin{array}{l}\text { Daskalakis and Psillaki } \\
\text { (2008) }\end{array}$ & $\begin{array}{l}\text { 1,252 SMEs from Greece and 2,006 } \\
\text { from France (1997-2002) }\end{array}$ & $\begin{array}{l}\text { Asset structure and profitability have a } \\
\text { negative relationship with leverage, } \\
\text { whereas firm size is positively related } \\
\text { to the debt to asset ratio. Growth is } \\
\text { statistically significant only for France } \\
\text { and is positively related to debt. } \\
\text { Differences in financing behavior } \\
\text { between the two countries are attributed } \\
\text { to firm-specific rather than country } \\
\text { factors. }\end{array}$ \\
\hline Liu and Tian (2009) & $\begin{array}{l}269 \text { SMEs and } 651 \text { Large-Sized } \\
\text { Enterprises (LSEs) in China (2005 - } \\
\text { 2008) }\end{array}$ & $\begin{array}{l}\text { Size discrimination (credit rationing to } \\
\text { smaller firms), pecking order behavior, } \\
\text { tax shield effects and a negative } \\
\text { relationship between state subsidies and } \\
\text { capital structure were found in the } \\
\text { sample of small-sized firms. Medium- } \\
\text { and large-sized non-state-owned firms } \\
\text { tend to have more bank loans than their } \\
\text { state-owned counterparts, while no such } \\
\text { relationship holds for small-sized firms. }\end{array}$ \\
\hline $\begin{array}{l}\text { Aybar-Arias, Casino- } \\
\text { Martinez and Lopez-Gracia } \\
(2012)\end{array}$ & 947 SMEs in Spain (1995-2005) & $\begin{array}{l}\text { SMEs display an average annual } \\
\text { adjustment speed towards their target } \\
\text { leverage of } 26 \% \text {. Adjustment speeds } \\
\text { are influenced by financial flexibility, } \\
\text { size, growth and the distance to the } \\
\text { optimal ratio. }\end{array}$ \\
\hline
\end{tabular}

Table 2

SME Capital Structure Studies Using Primary Data

\begin{tabular}{lll}
\hline Authors, Year & Database & Main Results \\
\hline $\begin{array}{l}\text { Hall, Hutchinson and } \\
\text { Michaelas (2004) }\end{array}$ & $\begin{array}{l}\text { 500 SMEs in Belgium, Germany, Spain, } \\
\text { Ireland, Italy, Netherlands, Portugal and are variations in both the SME } \\
\text { the UK (1995) }\end{array}$ & $\begin{array}{l}\text { capital structure and the determinants of } \\
\text { capital structure among the countries } \\
\text { surveyed. The existence of collateral } \\
\text { appears to be the strongest determinant, } \\
\text { while growth is the weakest. }\end{array}$ \\
\end{tabular}


Table 2 (continued)

\begin{tabular}{|c|c|c|}
\hline Authors, Year & Database & Main Results \\
\hline $\begin{array}{l}\text { Voulgaris, Asteriou and } \\
\text { Agiomirgianakis (2004) }\end{array}$ & $\begin{array}{l}143 \text { SMEs and } 75 \text { large } \\
\text { companies in Greece } \\
\text { (using balance sheets) } \\
\text { (2004) }\end{array}$ & $\begin{array}{l}\text { Profitability is a major determinant of the } \\
\text { financing decisions of large companies and } \\
\text { SMEs. Efficient asset management and asset } \\
\text { growth are important for large companies in } \\
\text { contrast with the efficiency of current assets, size, } \\
\text { sales, growth and fixed assets, which are more } \\
\text { important for the SME's financing decisions. }\end{array}$ \\
\hline $\begin{array}{l}\text { Machado, Temoche and } \\
\text { Machado (2004) }\end{array}$ & $\begin{array}{l}20 \text { SMEs in Paraiba, } \\
\text { Brazil (questionnaire) }\end{array}$ & $\begin{array}{l}\text { Size, risk, asset structure and liquidity are } \\
\text { relevant predictors of capital structure. }\end{array}$ \\
\hline Nakamura and Jucá (2005) & $\begin{array}{l}80 \text { (questionnaires) in } \\
\text { Brazil }\end{array}$ & $\begin{array}{l}\text { Profitability is negatively related to leverage, } \\
\text { consistent with pecking-order arguments. }\end{array}$ \\
\hline $\begin{array}{l}\text { Nguyen and Ramachandran } \\
(2006)\end{array}$ & $\begin{array}{l}558 \text { SMEs in Vietnam } \\
\text { (interviews) }\end{array}$ & $\begin{array}{l}\text { The capital structure of SMEs in Vietnam is } \\
\text { positively related to growth, business risk, firm } \\
\text { size, networking, and relationships with banks } \\
\text { but negatively related to tangibility. }\end{array}$ \\
\hline Abor (2008) & $\begin{array}{l}120 \text { SMEs in Ghana } \\
\text { (questionnaire) }\end{array}$ & $\begin{array}{l}\text { Agency problems are important determinants of } \\
\text { capital structure choices. }\end{array}$ \\
\hline Wu, Song and Zeng (2008) & $\begin{array}{l}60 \text { SMEs in } 4 \text { cities in } \\
\text { China (questionnaire) }\end{array}$ & $\begin{array}{l}\text { Idiosyncratic choices by owners related to } \\
\text { cultural and political issues are important. }\end{array}$ \\
\hline Dogra and Gubta (2009) & $\begin{array}{l}120 \text { SMEs in Punjab, } \\
\text { India (questionnaire) }\end{array}$ & $\begin{array}{l}\text { Entrepreneurs display a conservative attitude in } \\
\text { terms of capital structure choices, relying more } \\
\text { on internal funds than on outside financing, } \\
\text { regardless of the entrepreneur's level of } \\
\text { education. }\end{array}$ \\
\hline Briozzo and Vigier (2009) & $\begin{array}{l}129 \text { SMEs in Argentina } \\
\text { (questionnaire) }\end{array}$ & $\begin{array}{l}\text { There is a positive relationship between } \\
\text { entrepreneurial background and capital structure } \\
\text { choices. }\end{array}$ \\
\hline
\end{tabular}

\section{Method and Data Description}

The extant capital structure research using SMEs lacks homogeneity in terms of the methodological procedures utilized, partly as a consequence of the difficulty of obtaining financial data for these firms. In addition, even when a database is available, it is often not standardized or audited. Comparison and generalization therefore becomes more difficult and limited. This empirical literature has two main lines of research: questionnaire/survey based research and secondary data based research. The former approach tends to use smaller samples and search for behavioral patterns rather than proposing or testing theories, while the latter employs statistical procedures that are more familiar to the corporate finance literature, though with limited reach. In contrast, our research is based on an unprecedented panel with 19,272 SMEs spanning 13 years (1994-2006) of data, comprising a variety of firms based in the state of Sao Paulo, which has one of the largest GDPs in Latin America. The database was made available by Serasa-Experian, an accredited private provider of statistical and information services.

This dataset has information on the following balance sheet and income statement items: current liabilities, current assets, long-term liabilities, book equity, total assets, operating income, net income, depreciation, and sales. In addition, we know the year when each firm was founded and each firm's CNAE (National Classification of Economic Activities) number, which indicates its industry 
affiliations based on the classification provided by Instituto Brasileiro de Geografia e Estatística (IBGE - the Brazilian statistics bureau).

The main advantage of our approach is that we are able to apply advanced statistical procedures to a uniquely large and diversified sample, allowing us to find statistically reliable patterns in the distribution of the leverage ratios of SMEs. In particular, we test the extent to which most of the main predictors of leverage ratios featured in the literature help explain the cross-sectional differences in the capital structures of these firms. In addition, we are able to assess the dynamic and mean-reverting behavior of leverage over time. However, as in other quantitative SME studies, we are faced with important data limitations, which necessarily constrain the scope of our analysis. For example, our database has no information on the type and maturity of loans or on the share of interest-bearing versus non-interest-bearing financing. Therefore, we are unable to directly assess, for example, the extent to which our sample firms' debt comes from trade credit or bank loans. Additionally, we lack data on cash flows, dividend payments and capital expenditures, as well as on debt and equity issuance. Thus, we cannot test whether the financing deficits are closely tracked by new loans over time, as predicted by the pecking order hypothesis (see Frank \& Goyal, 2003; Lemmon \& Zender, 2010; Shyam-Sunder \& Myers, 1999).

\section{Potential determinants of the capital structure of small and medium enterprises}

Frank and Goyal (2008) surveyed a vast body of empirical work that used publicly traded firms and concluded that proxies for five firm-level characteristics appear to be reliably correlated with cross-sectional differences in leverage ratios: size, asset structure (tangibility), growth opportunities, profitability, and industry affiliation. Our dataset allows us to construct proxies for all of these variables. In addition, we include proxies for firm riskiness (within-firm volatility of profits). Below, we argue that these variables may also help explain the cross-sectional distribution of the leverage ratios of privately held SMEs.

\section{Size}

Firm size is usually used as a potential determinant of capital structure decisions (e.g., Kremp, Ströss, \& Gerdesmeier, 1999; Ozkan, 2001; Rajan \& Zingales, 1995; Titman \& Wessels, 1988). Studies in Brazil using publicly traded firms corroborate the importance of firm size (e.g., Martin et al., 2005; Perobelli \& Famá, 2001). Many reasons could be listed that justify the inclusion of size indicators, such as differential access to outside financing and credit markets, investment opportunities and riskiness related to scale.

In particular, the transaction costs associated with outside financing are likely to depend on size, both for publicly traded firms and for privately held SMEs, implying higher proportional transaction costs for smaller firms, which are enhanced in the event of financial distress or bankruptcy (Petersen \& Rajan, 1994; Titman \& Wessels, 1988; Wald, 1999).

The expected relationship between size and total leverage is thus clearly positive. Interestingly, some SME studies also report a negative relationship between size and short-term liabilities (Fluck, Holtz-Eakin, \& Rosen, 2000; Michaelas, Chittenden, \& Poutziouris, 1999), suggesting that relatively larger SMEs have enhanced access to and prefer longer-term financing.

\section{Asset structure}

Asset structure should matter for financing decisions. Firms, including SMEs, may use tangible assets as collateral, either providing more access to credit or reducing its cost, to the extent that such assets function as a guarantee in case of default (e.g., Gaud, Jani, Hoesli, \& Bender, 2005; Harris \& Raviv, 1991; Titman \& Wessels, 1988). Similarly, it has been argued that collateral reduces adverse selection and moral hazard costs (Colombo, 2001; Dewatripont, Legros, \& Matthews, 2003). 
Therefore, a positive relationship is expected between tangibility and leverage (e.g., Chittenden, Hall, \& Hutchinson, 1996; Jordan, Lowe, \& Taylor, 1998; Michaelas et al., 1999; Wijst \& Thurik, 1993).

\section{Growth}

The firms that experience high growth rates often need more aggressive financing. From a pecking order perspective, once these firms exhaust their internally generated funds, they will resort to debt financing. Therefore, for two firms with the same profitability, we should expect that the firm with a higher growth rate will be more leveraged. However, agency based (i.e., moral hazard) arguments suggest that debt may have an important disciplining effect on managers, reducing managerial discretion and thus preventing them from wasting corporate resources in value-destroying projects. In this context, high profitability but low-growth firms would benefit more from debt financing, which predicts a negative relationship between leverage and growth rates, ceteris paribus. However, this prediction is more likely to hold for firms with a clear separation of ownership and control, which is not the case for most SMEs. In any case, both a positive and a negative relationship could be theoretically supported. Using SME data from the UK, Michaelas, Chittenden and Poutziouris (1999) found that future growth is positively related to leverage and long-term debt, while Chittenden, Hall and Hutchinson (1996) and Jordan, Lowe and Taylor (1998) reported mixed evidence.

\section{Profitability and tax opportunities}

The relationship between firm performance (measured by its profitability ratio) and capital structure may be justified by the pecking order theory proposed by Myers and Majluf (1984). In this asymmetric information scenario, firms always prefer to finance investments with internally generated funds, which are not subjected to undervaluation by the providers of outside capital or to the restrictions and controls they are willing to impose (Babu \& Jain, 1998; Bond \& Meghir, 1994; Shyam-Sunder \& Myers, 1999). This argument should be especially relevant for privately owned SMEs because they are submitted to much less stringent governance requirements, including lower auditing and accounting procedures, when compared to their larger or publicly traded counterparts. Credit rationing problems (Stiglitz \& Weiss, 1981) are also likely to be prevalent for SMEs. In other words, besides charging higher interest rates, credit suppliers are more likely to simply restrict these firms' access to the credit market (Petersen \& Rajan, 1994), especially in less financially developed countries. Consistently, most of the few studies with SMEs show a negative relationship between leverage and profitability (e.g., Chittenden et al., 1996; Coleman \& Cohn, 2000; Jordan et al., 1998; Michaelas et al., 1999; Mishra \& McConaughy, 1999; Wijst \& Thurik, 1993).

However, it has also been argued that firms with better past performance have lower default risk and thus higher debt capacity. Therefore, they could seek more leverage to exploit the tax-shield benefit of debt (Fosberg, 2004; Homaifar, Zietz, \& Benkato, 1994; Omer \& Terando, 1999).

\section{Industry affiliation}

The body of research surveyed by Frank and Goyal (2008) suggests that industry leverage is an important predictor of firm leverage, at least for publicly traded firms. Industry affiliation may capture several otherwise omitted factors, such as industry specific regulatory restrictions and the influence of the type of business activity on the requirements for and access to external funding. Evidence is scarce for SMEs. One example is provided by Michaelas et al. (1999), who documented a significant industry effect on the leverage ratios of UK SMEs.

\section{Risk}

Intuitively, riskiness should be negatively related to leverage, considering the punishment for prospective defaults and bankruptcy, which is represented by substantially higher interest rates and 
expected bankruptcy costs when the firm approaches dangerous leverage levels. Several studies using listed companies report results that are compatible with this logic (e.g., Titman \& Wessels, 1988).

\section{Data, proxies and descriptive statistics}

Our panel is unbalanced, meaning that we do not require firms to be in the sample for the entire period from 1994 through 2006, thus avoiding any survivorship bias. Additionally, some financial indicators are missing for a substantial number of the sample firms in some or in all years, most likely because those firms did not send the requested information to Serasa-Experian. However, (a) our preliminary analysis did not find any pattern in the distribution of the missing data, which suggests that it does not bias our inferences, and (b) although in some regressions the combined missing data drastically reduces the usable sample, it still leaves us with a minimum of over 4,400 firms with complete data. Additionally, our primary inferences are robust to variations in the number of usable firms caused by the exclusion or inclusion of variables with many missing values.

Following most of the empirical capital structure literature, we winsorize our leverage indicators and the majority of our proxies for the potential determinants of capital structure to reduce the influence of outliers. Indeed, our preliminary analysis revealed a few very unrealistic figures for many financial indicators such as liabilities, assets and operating income, possibly because of input error. Therefore, all analyses described below use variables that are winsorized at $10 \%$ (i.e., replacing the $10 \%$ highest and $10 \%$ lowest values for the next value counting inwards from the extremes). Additionally, we exclude from the regressions all firm years with negative book equity. Table 3 summarizes the variables used in the research and Table 4 shows the descriptive statistics.

Table 3

Proxies for Leverage, Potential Determinants of Capital Structure, and Control Variables

\begin{tabular}{|c|c|c|}
\hline Code & Variable & Operating definition \\
\hline \multirow{2}{*}{ Leverage } & \multirow{2}{*}{ Total Leverage } & Current Liabilities + Long Term Liabilities \\
\hline & & Total Asset \\
\hline \multirow{2}{*}{ Leverage } & \multirow{2}{*}{$\begin{array}{l}\text { Long-Term (LT) } \\
\text { Leverage }\end{array}$} & Long Term Liabilities \\
\hline & & Total Asset \\
\hline \multirow{2}{*}{ Growth } & \multirow{2}{*}{ Sales Growth } & Sales $_{t}-$ Sales $_{t-1}$ \\
\hline & & Sales $_{t-1}$ \\
\hline \multirow{2}{*}{ Growth } & \multirow{2}{*}{ Asset Growth } & Asset $_{t}-$ Asset $_{t-1}$ \\
\hline & & Asset $_{t-1}$ \\
\hline \multirow{2}{*}{ Profitability } & \multirow{2}{*}{$\begin{array}{c}\text { Profitability } \\
\text { (Operating Income) }\end{array}$} & Operating Income \\
\hline & & Total Asset \\
\hline \multirow{2}{*}{ Profitability } & \multirow{2}{*}{ Profitability (ROE) } & Net Income \\
\hline & & $\overline{\text { Book Equity }}$ \\
\hline Size & Sales & $\ln ($ Sales $)$ \\
\hline
\end{tabular}


Table 3 (continued)

\begin{tabular}{|c|c|c|}
\hline Code & Variable & Operating definition \\
\hline Size & Assets & $\ln ($ Total Asset $)$ \\
\hline Age & Firm Age in 2006 & Number of years (in 2006) since the foundation of the firm \\
\hline Asset & Depreciation & Depreciation \\
\hline Structure & Expenses & Total Asset \\
\hline Asset & Non-Debt Tax & Depreciation \\
\hline Structure & Shield & $\overline{\text { Operating Income }}$ \\
\hline Risk & $\begin{array}{l}\text { Volatility of } \\
\text { Profitability }\end{array}$ & $\begin{array}{l}\text { Five-year rolling standard deviation of the profitability ratio (using Operating } \\
\text { Income) }\end{array}$ \\
\hline Industry & Industry Dummies & $\begin{array}{c}\text { Dummy indicating if the firm belongs to each of the } 21 \text { industries in the CNAE } \\
\text { classification by IBGE (the Brazilian statistics bureau) }\end{array}$ \\
\hline Year & Year Dummies & $\begin{array}{l}\text { Dummy that takes the value } 1 \text { in year } t \text { and } 0 \text { otherwise, where } \\
\qquad t=1994, \ldots, 2006\end{array}$ \\
\hline
\end{tabular}

Table 4

Descriptive Statistics

\begin{tabular}{lccccc}
\hline Variable & Obs & Mean & SD & Min & Max \\
\hline Total Leverage & 207,921 & 0.510 & 0.302 & 0.0962 & 1.004 \\
Long-Term (LT) Leverage & 206,987 & 0.103 & 0.151 & 0 & 0.437 \\
Sales Growth & 180,523 & 0.194 & 0.313 & -0.214 & 0.825 \\
Asset Growth & 183,954 & 0.187 & 0.268 & -0.147 & 0.724 \\
Profitability (Operating Income) & 207,498 & 0.0865 & 0.169 & -0.169 & 0.401 \\
Profitability (ROE) & 205,868 & 0.116 & 0.263 & -0.324 & 0.595 \\
Sales & 204,711 & $7,359,000$ & $9,414,000$ & 360,502 & $29,690,000$ \\
Assets & 207,927 & $5,452,000$ & $7,781,000$ & 163,173 & $24,360,000$ \\
Age (in 2006) & 250,536 & 25.16 & 10.49 & 6 & 99 \\
Depreciation Expenses/Assets & 18,105 & 0.0196 & 0.0232 & -0.00684 & 0.0682 \\
Non-Debt Tax Shield & 18,104 & 0.0595 & 0.351 & -0.576 & 0.734 \\
Volatility of Profitability & 166,305 & 0.0918 & 0.0582 & 0.0165 & 0.197 \\
\hline
\end{tabular}

Note. Sales and Assets are in original values (in Brazilian Real - BRL). Obs is the number of non-missing observations, SD is the standard deviation, Min is the minimum and Max is the maximum value of the variable. Except for Age, all variables are winsorized at $10 \%$. 
Table 4 shows that the two asset structure proxies have a great number of missing observations because most firms did not report their depreciation. For this reason, we also run regressions without these proxies as a robustness check. We also note that our sample is quite heterogeneous in terms of firm age - the average firm was (in 2006) 25 years old, with a maximum age of 99 years and a minimum of six.

When we segment the descriptive analysis by year, the most remarkable pattern, shown in Figure 1 and Table 5, is that the mean and median total leverage increases monotonically throughout the sample period (though at a slower pace after 2004) and their long-term and short-term components grow at similar rates. Mean and median comparison tests show that the increase from the previous year is statistically significant at conventional levels for most years. In contrast, Figure 1 also shows that the profitability ratio does not have a discernible trend, and the same is true for most of the remaining variables in our dataset. The increase in the mean leverage ratios is not driven by sample attrition; i.e., by lower leverage firms systematically dropping from the sample or by higher leverage firms entering the sample during this period. If we restrict the analysis to a balanced sample comprising the 6,313 firms with data for all 13 years, the picture is virtually unchanged. Although a detailed investigation of the causes of this trend is beyond the scope of this paper, it suggests that the stabilization and improvements in the Brazilian economy after 1994 have eased SMEs' access to credit markets. Consistent with this story, our regression analyses show that the mean leverage significantly increases over time even after controlling for (i.e., holding constant) asset size, sales, profitability or industry composition. It is also interesting to note that the mean and median within-firm standard deviation of the profitability ratio decreases monotonically during the sample period, suggesting that operating profitability became less volatile for the average firm over time. Table 5 also shows, for each sample year, the total number of firms with available data (even if incomplete, i.e., missing information about one or more variables). To partly account for inflation, the total assets are shown in US\$ in Figure 1 and Table 5 (the conversion uses year-end PTAX US\$/BRL exchange rates). 

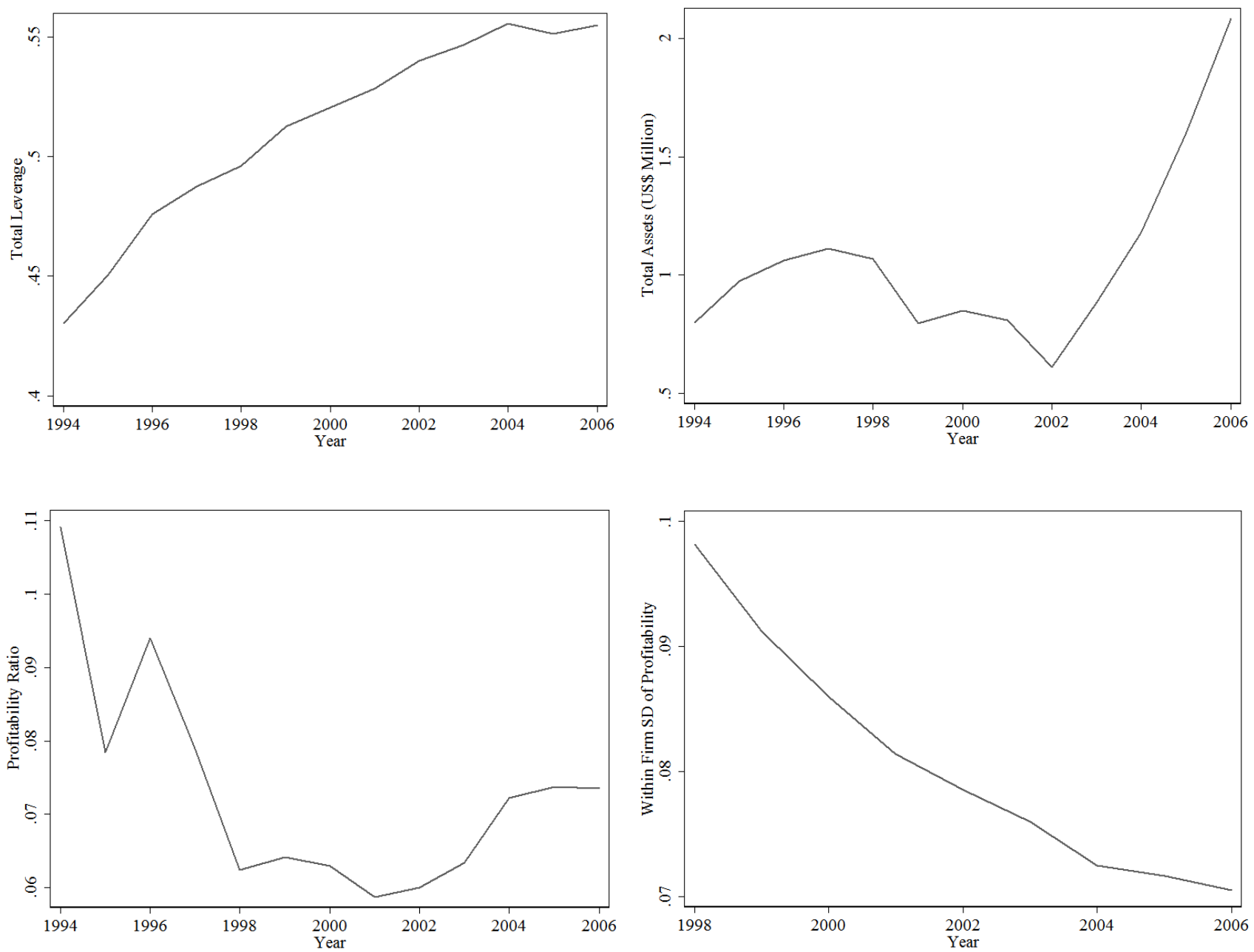

Figure 1. Median Values of Total Leverage, Total Assets (in US\$ millions), Operating Profitability Ratio, and the Within-firm 5-year Standard Deviation of the Profitability Ratio.

Table 5

Number of Firms and Sample Median Values of the Selected Variables by Year

\begin{tabular}{crrrrr}
\hline Year & Number of Firms & Total Leverage & $\begin{array}{c}\text { Total Assets (in } \\
\text { US\$) }\end{array}$ & $\begin{array}{c}\text { Profitability } \\
\text { (Operating Income) }\end{array}$ & $\begin{array}{c}\text { Volatility of } \\
\text { Profitability }\end{array}$ \\
\hline 1994 & 13,415 & 0.389 & 767,786 & 0.097 & \\
1995 & 14,546 & 0.412 & 912,967 & 0.064 & \\
1996 & 15,386 & 0.430 & $1,004,444$ & 0.079 &. \\
1997 & 16,327 & 0.439 & $1,040,048$ & 0.065 &. \\
1998 & 17,388 & 0.445 & $1,004,179$ & 0.050 & 0.099 \\
1999 & 18,167 & 0.471 & 737,505 & 0.051 & 0.092 \\
2000 & 18,162 & 0.496 & 788,724 & 0.049 & 0.087 \\
2001 & 18,360 & 0.510 & 750,406 & 0.045 & 0.082 \\
2002 & 17,569 & 0.527 & 562,323 & 0.043 & 0.079 \\
2003 & 16,556 & 0.533 & 808,572 & 0.047 & 0.077 \\
\hline
\end{tabular}


Table 5 (continued)

\begin{tabular}{cccccc}
\hline Year & Number of Firms & Total Leverage & $\begin{array}{c}\text { Total Assets (in } \\
\text { US\$) }\end{array}$ & $\begin{array}{c}\text { Profitability } \\
\text { (Operating Income) }\end{array}$ & $\begin{array}{c}\text { Volatility of } \\
\text { Profitability }\end{array}$ \\
\hline 2004 & 15,458 & 0.538 & $1,075,190$ & 0.055 & 0.074 \\
2005 & 14,302 & 0.531 & $1,446,212$ & 0.059 & 0.073 \\
2006 & 12,291 & 0.535 & $1,872,188$ & 0.057 & 0.072 \\
\hline
\end{tabular}

Note. Volatility of Profitability is the within-firm standard deviation of Profitability (based on operating income) using the previous five years. Total assets are converted to US\$ using year-end PTAX US\$/BRL exchange rates.

The most synthetic level of the CNAE classification includes 21 industries, 19 of which are represented in our sample - the exceptions are Domestic Services and Multilateral Institutions and Other Foreign Institutions. We further exclude two industries: Public Management, Defense and Social Security and Financial Services, Insurance and Related. The first group may contain notfor-profit government or public service providers, such as research agencies, while the latter contains financial services firms, which are not easily comparable to non-financial firms. Table 6 shows the distribution of our sample across the remaining 17 categories. Retail and Manufacturing firms are prevalent in the sample, accounting for $33.60 \%$ and $28.97 \%$ of all firms, respectively. The third largest category is Construction, followed by Transportation and Management Services. Retail, Management Services, and Manufacturing firms tend to be more financially leveraged than the firms in other industries, and we find (in unreported mean comparison tests) that these differences are statistically significant in most cases.

Table 6

Percentage Number of Firms and Sample Median Values of Selected Variables by Industry

\begin{tabular}{lccccc}
\hline Industry & Frequency & $\begin{array}{c}\text { Total } \\
\text { Leverage }\end{array}$ & $\begin{array}{c}\text { Total Assets } \\
\text { (in BRL) }\end{array}$ & $\begin{array}{c}\text { Profitability } \\
\text { (Operating } \\
\text { Income) }\end{array}$ & $\begin{array}{c}\text { Volatility of } \\
\text { Profitability }\end{array}$ \\
\hline Agriculture & $1.69 \%$ & 0.277 & $4,669,106$ & 0.002 & 0.063 \\
Arts, Culture, Sports and Recreation & $0.44 \%$ & 0.158 & $2,686,853$ & 0.015 & 0.057 \\
Catering and Housing & $1.23 \%$ & 0.344 & 711,020 & 0.045 & 0.085 \\
Construction & $9.60 \%$ & 0.418 & $2,188,763$ & 0.045 & 0.082 \\
Education & $1.46 \%$ & 0.481 & $1,540,421$ & 0.040 & 0.091 \\
Electricity and Gas & $0.19 \%$ & 0.362 & $24,355,103$ & 0.041 & 0.051 \\
Extractive Industries & $0.44 \%$ & 0.290 & $2,693,200$ & 0.019 & 0.071 \\
Health and Social Services & $3.32 \%$ & 0.440 & $1,235,119$ & 0.108 & 0.079 \\
Information and Communication & $2.66 \%$ & 0.489 & $1,862,328$ & 0.097 & 0.091 \\
Management Services & $3.95 \%$ & 0.529 & $1,401,141$ & 0.070 & 0.090 \\
Manufacturing & $28.97 \%$ & 0.502 & $3,159,166$ & 0.049 & 0.078 \\
Other & $1.34 \%$ & 0.220 & $2,652,629$ & 0.055 & 0.076 \\
Professional, Technical and Scientific & & & & & \\
Services & $3.32 \%$ & 0.427 & 987,475 & 0.184 & 0.091 \\
Real Estate & $1.77 \%$ & 0.240 & $2,821,087$ & 0.034 & 0.053 \\
\hline
\end{tabular}


Table 6 (continued)

\begin{tabular}{lccccc}
\hline Industry & Frequency & $\begin{array}{c}\text { Total } \\
\text { Leverage }\end{array}$ & $\begin{array}{c}\text { Total Assets } \\
\text { (in BRL) }\end{array}$ & $\begin{array}{c}\text { Profitability } \\
\text { (Operating } \\
\text { Income) }\end{array}$ & $\begin{array}{c}\text { Volatility of } \\
\text { Profitability }\end{array}$ \\
\hline Retail & $33.60 \%$ & 0.511 & 681,164 & 0.067 & 0.084 \\
Transportation & $5.71 \%$ & 0.500 & $1,958,805$ & 0.022 & 0.084 \\
Water Supply and Waste Management & $0.29 \%$ & 0.406 & $4,714,864$ & 0.051 & 0.083 \\
\hline
\end{tabular}

\section{Empirical model}

The regressions are based on the dynamic linear model depicted by equation (1):

$$
\begin{aligned}
& \text { Leverage }_{i, t}=\text { aLeverage }_{i, t-1}+\beta_{1} \text { Size }_{i, t}+\beta_{2} \text { AssetStructure }_{i, t}+\beta_{3} \text { Profitability }_{i, t}+ \\
& \beta_{4} \text { Volatility }_{i, t}+\beta_{5} \text { Growt }_{i, t}+\beta_{6} \text { Age }_{i, t}+\sum_{j \epsilon J} \delta_{j} \text { Industry }_{j, i, t}+\mu_{i+} d_{t+} \varepsilon_{i, t}
\end{aligned}
$$

where $\varepsilon$ is the error term, $\mu_{i}$ represents the i-th firm's time invariant unobserved features that might influence its debt/equity decision, and $d_{t}$ stands for time fixed effects (i.e., the common effect of any shock to Leverage in time $t$ ). Implemented in the form of a set of year dummies included in all regressions, $d_{t}$ effectively controls for macroeconomic shocks that may affect the capital structure of firms, such as changes in the interest rate and inflation. The lagged dependent variable accounts for possible inertial or mean reversion effects in the dynamics of leverage. The remaining regressors are described above, except for Age. Although most previous papers do not feature age as a determinant of capital structure, we argue that the age of the firm (in log form) serves as a control for the potential differential access of older firms to the credit market (e.g., creditors may consider them to be safer, which enhances their debt capacity) or a potential heterogeneity in their appetite for risk (i.e., the owners or managers of older firms may become more conservative and therefore favor equity financing).

The adequacy of a dynamic specification to model firms' capital structure decisions is attested to by several panel data studies (e.g., Gaud et al., 2005; Martin et al., 2005), including a few with SMEs (e.g., López-Gracia \& Sogorb-Mira, 2008). This specification addresses the possibility that firms set a target (or optimal) debt/equity ratio and adjust their actual leverage towards that target, although imperfectly (i.e., it is a partial adjustment process). Even if firms do not work with a target leverage ratio, however, the lagged dependent variable is important to control for the time persistence of this variable. In fact, the diagnostic tests that we run after all estimations confirm the need to include one or more lags of the dependent variable among the regressors.

The results reported in Table 7 were obtained using the traditional Pooled Ordinary Least Squares (POLS) estimator and the more advanced System GMM (GMM-Sys) procedure described in Blundell and Bond (1998).

The System GMM allows us to explicitly model firm unobserved fixed effects represented by $\mu_{i}$ and to consistently include the lagged dependent variable among the regressors, unlike other panel data estimators, such as the well-known Fixed Effects and Random Effects estimators. By controlling for $\mu_{i}$, we are able to mitigate the biases arising from potentially omitted variables that are correlated with our regressors, such as managerial competence, market power and governance quality, to the extent that they are invariant throughout the sample period. In addition, GMM-Sys also enables us to address the likely endogenous relationship between our proxies for the determinants of capital structure and the leverage ratio by using the lagged values of the regressors as instrumental variables. In our case, maybe the most important problem is what has been termed dynamic endogeneity (e.g., Wintoki et al., 2012) or the feedback effect, which is caused by the potential influence of $\varepsilon_{i, t}$ (shocks that affect the leverage ratio) on the regressors in future periods. For example, changes in governance, 
technology or management may contemporaneously affect the capital structure decision and may also affect firm growth, sales or profitability in subsequent periods. Ignoring this issue will cause our estimator to be inconsistent and will lead us to erroneous inferences. Indeed, the diagnostic tests that we run (e.g., Breusch-Pagan, Hausman and Hansen/Sargan tests) strongly suggest that the GMM-Sys estimator should be preferred.

\section{Regression Results}

Table 7 shows the primary results from the regressions that we estimate based on equation (1). In both GMM-Sys models, we use suitable lagged values of the regressors as instruments, allowing them to be correlated with the error term in future periods and/or contemporaneously. By doing this, we address the endogeneity issues discussed above and reduce concerns about potentially spurious inferences. The exception is Age and the industry and year dummies, which are assumed to be strictly exogenous (i.e., non-correlated with the error in any time period). The diagnostic tests reported in the table indicate that our identifying assumptions are statistically plausible.

The first inference from Table 7 is that Leverage is highly persistent. In fact, Leverage $_{t-1}$ is the most relevant regressor in our model, in addition to being correlated with some of the potential determinants of capital structure, thus leaving little doubt regarding the importance of modeling financing decisions as a dynamic process. This result is consistent with the findings of many previous empirical studies that used panel data sets (e.g., Martin et al., 2005, using Brazilian listed firms).

Additionally, our proxy for profitability clearly stands out as a very relevant determinant of the leverage ratio. Unsurprisingly, the sign of the coefficient is negative, which is compatible with the pecking order arguments based on asymmetric information, transaction costs or credit rationing (i.e., restricted access of SMEs to credit markets). These results do not lend support, in contrast, to the trade-off based arguments, according to which highly profitable firms should be more financially leveraged because they have less default risk and may reap a potentially larger tax benefit from debt. The estimates are both statistically and economically significant and the effect is larger for short-term than for long-term leverage ratios. The estimates are also remarkably robust to changes in the specification of the model and in the proxy for profitability and are substantially larger in the GMMSys regressions, which further suggests that there is a causal negative link between profitability and leverage.

The other robust inference is the positive influence of asset growth on leverage, although it has a smaller magnitude than profitability. This result suggests that high growth SMEs tend to resort to debt to finance their expansion, at least after they have exhausted their internally generated funds, which is again consistent with pecking order behavior. The fact that the coefficient estimates are larger for short-term than for long-term leverage is further compatible with financing restrictions; that is, firms find it harder to finance their expansion with long-term debt. The influence of the growth rate is less clear, however, when we use sales growth instead of asset growth.

We find weaker evidence that the relatively larger SMEs have increased debt capacity. The coefficient estimates for our size proxy have positive signs in all regressions, as expected. However, the estimates show that this influence, when statistically significant, is less relevant economically. 
Table 7

\section{Regression Results}

\begin{tabular}{|c|c|c|c|c|}
\hline & \multicolumn{2}{|c|}{ Total Leverage } & \multicolumn{2}{|c|}{ Long Term Leverage } \\
\hline & POLS & GMM-Sys & POLS & GMM-Sys \\
\hline \multirow[t]{2}{*}{ Leverage $\mathrm{t}-1$} & $0.796 * * *$ & $0.659 * * *$ & $0.774 * * *$ & $0.723 * * *$ \\
\hline & $(152.232)$ & $(21.028)$ & (104.192) & $(29.784)$ \\
\hline \multirow[t]{2}{*}{ Size } & $0.003 * * *$ & $0.009 * *$ & $0.001 * *$ & 0.001 \\
\hline & $(3.487)$ & $(2.016)$ & $(2.232)$ & $(0.495)$ \\
\hline \multirow[t]{2}{*}{ Asset Structure } & $0.116 * *$ & -0.236 & -0.019 & -0.172 \\
\hline & (1.994) & $(-0.961)$ & $(-0.552)$ & $(-1.090)$ \\
\hline \multirow[t]{2}{*}{ Profitability } & $-0.378 * * *$ & $-0.495 * * *$ & $-0.107 * * *$ & $-0.123 * * *$ \\
\hline & $(-36.764)$ & $(-12.436)$ & $(-21.036)$ & $(-5.523)$ \\
\hline \multirow[t]{2}{*}{ Volatility } & -0.024 & $-0.108 * *$ & $-0.034 * * *$ & $-0.071 * *$ \\
\hline & $(-1.200)$ & $(-1.972)$ & $(-2.983)$ & $(-2.291)$ \\
\hline \multirow[t]{2}{*}{ Growth } & $0.126 * * *$ & $0.144 * * *$ & $0.030 * * *$ & $0.026 * * *$ \\
\hline & (19.418) & $(17.069)$ & $(8.043)$ & $(5.441)$ \\
\hline \multirow[t]{2}{*}{ Age } & $-0.008 * * *$ & $-0.023 * * *$ & 0.002 & 0.000 \\
\hline & $(-2.957)$ & $(-5.080)$ & $(1.186)$ & $(0.241)$ \\
\hline Industry Dummies & YES & YES & YES & YES \\
\hline Year Dummies & YES & YES & YES & YES \\
\hline Observations & 15,340 & 15,340 & 15,322 & 15,322 \\
\hline R-squared & 0.794 & - & 0.677 & - \\
\hline F-Test & $1417(<.001)$ & $83.69(<.001)$ & $602(<.001)$ & $116(<.001)$ \\
\hline Hansen $\mathbf{J}$ & - & $\begin{array}{c}317 \\
(293 ; 0.161)\end{array}$ & - & $\begin{array}{c}290.6 \\
(307 ; 0.741)\end{array}$ \\
\hline $\mathrm{m} 1$ & - & $-13.13(<.001)$ & - & $-14.25(<.001)$ \\
\hline $\mathrm{m} 2$ & - & $-0.44(0.657)$ & - & $0.11(0.915)$ \\
\hline
\end{tabular}

Note. The reported regressions use Total Leverage as the dependent variable and are estimated using Pooled Ordinary Least Squares (POLS) and the System Generalized Method of Moments estimator (GMM-Sys) proposed by Blundell, R., \& Bond, S. R. (1998). Initial conditions and moment restrictions in dynamic panel data models. Journal of Econometrics, 87(1), 115143. doi: 10.1016/S0304-4076(98)00009-8. The regressors are the lagged total or long-term leverage (Leverage t-1 $_{t}$ ), (ln(Sales)), Asset Structure (Depreciation/TotalAsset), Profitability (Operating Income/Total Asset), Volatility (5year within-firm standard deviation of the profitability ratio), Growth ((Asset $t_{t}-$ Asset $\left._{t-1}\right) /$ Asset $\left._{t-1}\right)$, Age (Firm Age in 2006) and a set of industry and year dummy variables. All of the variables are winsorized at $10 \%$ and the firm years with negative equity are excluded. POLS regressions use firm-clustered standard errors, which are robust to arbitrary forms of heteroskedasticity and autocorrelation of the error term, and GMM-Sys regressions employ two-step bias-corrected robust standard errors. The estimated coefficients are shown in bold, with t-statistics below (in parenthesis). F-test statistics are reported with p-values in parenthesis; Hansen $\mathbf{J}$ is the Hansen/Sargan (heteroskedasticity robust) test of over identifying restrictions. The test statistics are shown with degrees of freedom and $\mathrm{p}$-values, respectively, in parenthesis; $\mathrm{m} 1$ and $\mathrm{m} 2$ are the Arellano-Bond first and second-order autocorrelation tests, respectively. The test statistics are shown with the p-values in parenthesis.

$* p<0.10 . * * p 0.05 . * * * p<0.001$.

In some least squares regressions, we find a positive relationship between asset structure (Depreciation/Total Asset) and leverage, but this result is most likely spurious because it completely disappears in all models estimated using GMM-Sys. Finally, there is weak evidence that both 
Volatility and Age are negatively related to Leverage. This evidence appears to imply that older SMEs tend to be (slightly) more conservative than younger ones - favoring equity over debt financing - while, as expected, the firms with more volatile profits tend to be less levered, either because they have less debt capacity or because they are less inclined toward this type of financing. We should be cautious with these inferences, however, because the significance of these coefficients is highly sensitive to the model specification. We find qualitatively similar results in the regressions excluding Depreciation/Total Asset and in the regressions using Depreciation/Operating Income as the proxy for asset structure.

\section{Speed of adjustment}

A now extensive empirical literature (surveyed by Frank \& Goyal, 2008; Oztekin \& Flannery, 2012) shows that leverage ratios are persistent through time and tend to mean revert. This evidence is also consistent with firms having a target leverage ratio and partially adjusting actual leverage towards the target when it moves away from it. To see this, consider the following partial adjustment equation:

$$
\text { Leverage }_{i, t}-\text { Leverage }_{i, t-1}=\lambda\left(\text { Leverage }_{i, t}^{*}-\text { Leverage }_{i, t-1}\right)+\varepsilon_{i, t}
$$

where Leverage $e_{i, t}$ is the actual leverage ratio of firm $i$ in year $t$, Leverage $_{i, t}^{*}$ is its target (or optimal) leverage ratio, and $\varepsilon_{i, t}$ is a random disturbance with a zero expected value. Equation (2) states that the deviations from the target leverage are corrected at a rate equal to $\lambda$ each year. If $\lambda=1$, the actual and the target leverage are expected to be equal, implying that fluctuations around the target are corrected promptly. On the other extreme, if $\lambda=0$, there is no adjustment and leverage will only change randomly. Although we cannot directly observe target leverage, it can be specified as a function of observed and unobserved firm characteristics plus macroeconomic conditions, as shown in equation (3):

$$
\text { Leverage }_{i, t}^{*}=\Gamma X_{i, t}+u_{i}+v_{t}
$$

where $u_{i}$ and $v_{t}$ are firm and time fixed effects, respectively, and $X_{i, t}$ is a vector of the time-varying determinants of financing decisions, such as profitability, size, and growth opportunities. By substituting equation (3) in (2) and rearranging, we find

$$
\text { Leverage }_{i, t}=(1-\lambda) \text { Leverage }_{i, t-1}+\lambda \Gamma X_{i, t}+\lambda u_{i}+\lambda v_{t}+\varepsilon_{i, t}
$$

Equation (4) is exactly equivalent to our specification shown in equation (1) (letting $\mu_{i} \equiv \lambda u_{i}$ and $d_{t} \equiv \lambda v_{t}$ ) when the components of $X_{i, t}$ are the independent variables in our regressions. In this context, we can interpret $\alpha$, the coefficient of Leverage $e_{i, t-1}$, as being equivalent to $1-\lambda$. For example, in the first column of Table 7, $\hat{\alpha}=1-\hat{\lambda}=0.796$. Thus, $\hat{\lambda}=0.204$, implying an average annual adjustment rate of $20.4 \%$. In other words, it would take approximately three years for the average firm to close half of the gap between its target and its actual leverage ratios ${ }^{(1)}$.

This speed of adjustment is consistent with the recent international evidence provided by Oztekin and Flannery (2012). These authors estimated the speed of adjustment of publicly traded firms in 37 countries using 16 years of data. They report an overall mean $\hat{\lambda}$ of $21.11 \%$. Using a sample of 140 Brazilian publicly traded firms, the same authors report estimates ranging from $13.29 \%$ to $25.90 \%$ (which lie below their sample median estimates), depending on the method of estimation. Oztekin and Flannery (2012) also report that $\hat{\lambda}$ is larger in countries with more developed capital markets and fewer restrictions on outside financing. Thus, a relatively low speed of adjustment may result from financing frictions related to high transaction costs or capital rationing.

Evidence on the speed of adjustment of SMEs is still scarce. The most detailed study so far is offered by Aybar-Arias, Casino-Martinez and Lopez-Gracia (2012) using a sample of 947 Spanish SMEs. Their average adjustment speed estimate is $26 \%$, which lies between our OLS (20.4\%) and GMM-Sys (34.1\%) estimates. We note, however, that finding mean reversion in leverage ratios (i.e., 
$\hat{\lambda}>0$ ) is compatible with but does not prove that firms have a target capital structure (Shyam-Sunder $\&$ Myers, 1999). Therefore, this evidence is not sufficient to reject the pecking order hypothesis.

\section{Conclusion}

This research investigates the determinants of the debt/equity decisions of small and medium enterprises. In the first part of the paper, we review the theoretical capital structure literature and, more importantly, the still-incipient empirical research dedicated to investigating the financing structure of SMEs in several countries. We find two primary distinct research approaches in this field: (a) one based on primary data collected through surveys, questionnaires and interviews and (b) another based on secondary data collected in databases. The former approach is generally associated with more qualitative analyses, using smaller samples and seeking to describe patterns or identify behaviors, rather than to propose or test theories. The latter approach is associated with quantitative research and uses larger samples and statistical methods primarily to test the adequacy of capital structure theories as applied to SMEs.

In the second part of the paper, we conduct our empirical analysis using an unprecedented database provided by Serasa-Experian with over 19,000 Brazilian firms based in the state of Sao Paulo, spanning 13 years of data from 1994 through 2006. This large panel is unbalanced, meaning that we allow firms to enter or leave the sample during the referred period, thus avoiding any survivorship bias. Additionally, even after removing potential outliers and despite the large number of missing values for some variables, we were able to use a minimum of over 4,400 firms with complete data in our reported regressions, which were estimated using traditional (e.g., Ordinary Least Squares) and advanced (e.g., dynamic panel System GMM) procedures.

We find a strong and robust negative relationship between profitability and the leverage ratio, consistent with most of the extant empirical literature, either using publicly traded firms or SMEs. In all regressions, the estimated coefficients for our profitability proxies are both statistically and economically significant, though with smaller magnitudes when we use long-term leverage as the dependent variable, showing a clear tendency for the more profitable SMEs to be less leveraged. This result is predicted by the pecking order arguments and may also be interpreted as evidence of the limited access Brazilian SMEs have to outside financing. A second robust result is the positive relationship between leverage and the growth rate (measured by annual asset growth), again with smaller magnitudes in the long-term leverage regressions. This result is also compatible with the pecking order theory (i.e., the prediction that firms will resort to debt financing after exhausting internally generated funds) because we control for profitability and size, as well as for other firm characteristics (either observed or unobserved).

We also find evidence that (a) size is positively related to leverage, which can be interpreted as evidence that larger firms have more access to outside financing in general and credit markets in particular; (b) riskier SMEs (measuring risk as the within-firm volatility of profits) tend to be less financially leveraged, consistent with the bankruptcy costs arguments from trade-off based theories; and (c) the age of the firm is negatively related to financial leverage (when we use total leverage as the dependent variable), suggesting that older SMEs may be marginally more conservative in their financing choices. However, these results are weaker because the statistical significance of the estimates is sensitive to the regression specification.

The empirical analysis also investigates the dynamic behavior of the leverage ratios in our sample. We find that capital structure is highly persistent. Indeed, lagged leverage is the best predictor of subsequent leverage in all regressions. This evidence is compatible with the hypothesis that SMEs adjust their debt/equity ratio towards a target value, but at a low speed, which is consistent with firms facing high transaction costs when choosing their financing mix. Our estimates for the speed of adjustment parameter are consistent with the available international evidence. 
This study could be extended in several ways using more detailed firm-level data than we have available. For example, further research might address the extent to which SMEs use non-bank (e.g., trade credit) versus bank-related financing and how this behavior evolved over time conditioned on micro- and macro-economic changes. Additionally, it would be interesting to closely examine the role of subsidized lending (e.g., provided by Banco Nacional de Desenvolvimento Econômico e Social BNDES, a major Brazilian development bank) to selected firms and how it helped shape their observed capital structure.

\section{Acknowledgments}

We are grateful to Ricardo Leal (the Associate Editor), two anonymous reviewers, and ENANPAD seminar participants for valuable comments. We also thank Serasa-Experian for providing the dataset and gratefully acknowledge the financial support of MackPesquisa and CNPq.

\section{Note}

${ }^{1}$ The calculation is $\ln (0.5) / \ln (1-0.204)$. See Oztekin and Flannery $(2012)$ for details.

\section{References}

Abor, J. (2007). Debt policy and performance of SMEs evidence from Ghanaian and South African firms. The Journal of Risk Finance, 8(4), 364-379. doi: 10.1108/15265940710777315

Abor, J. (2008). Agency theoretic determinants of debt levels: evidence from Ghana. Review of Accounting and Finance, 7(2), 183-192. doi: 10.1108/14757700810874146

Aybar-Arias, C., Casino-Martinez, A., \& Lopez-Gracia, J. (2012). On the adjustment speed of SMEs to their optimal capital structure. Small Business Economics, 39(4), 977-996. doi: $10.1007 / \mathrm{s} 11187-011-9327-6$

Babu, S., \& Jain, P. K. (1998). Empirical testing of pecking order hypothesis with reference to capital structure practices in India. Journal of Financial Management \& Analysis, 11(2), 63-74.

Baker, M., \& Wurgler, J. (2002). Market timing and capital structure. The Journal of Finance, 57(1), 1-32. doi: $10.1111 / 1540-6261.00414$

Benito, A. (2003). The capital structure decisions of firms: is there a pecking order? [Working Paper $\mathrm{n}^{\circ}$ 0310]. Banco de Espana, Madrid, Spain.

Blundell, R., \& Bond, S. R. (1998). Initial conditions and moment restrictions in dynamic panel data models. Journal of Econometrics, 87(1), 115-143. doi: 10.1016/S0304-4076(98)00009-8

Bond, S. R., \& Meghir, C. (1994). Dynamic investment models and the firm's financial policy. Review of Economic Studies, 61(2), 197-222. doi: 10.2307/2297978

Briozzo, A., \& Vigier, H. (2009). A demand-side approach to SMES' capital structure: evidence from Argentina. Journal of Business and Entrepreneurship, 21(1), 30-56.

Cassar, G., \& Holmes, S. (2003). Capital structure and financing of SMEs: Australian evidence. Accounting and Finance, 43(2), 123-147. doi: 10.1111/1467-629X.t01-1-00085 
Chittenden, F., Hall, H., \& Hutchinson, P. (1996). Small firm growth, access to capital markets and financial structure: review of issues and an empirical investigation. Small Business Economics, 8(1), 59-67. doi: 10.1007/BF00391976

Coleman, S., \& Cohn, R. (2000). Small firms' use of financial leverage: evidence from the 1993 national survey of small business finances. Journal of Business Entrepreneurship, 12(3), 81-98.

Colombo, E. (2001). Determinants of corporate capital structure: evidence from Hungarian firms. Applied Economics, 33(13), 1669-1701. doi: 10.1080/00036840010015057

Daskalakis, N., \& Psillaki, M. (2008). Do country or firm factors explain capital structure? Evidence from SMEs in France and Greece. Applied Financial Economics, 18(2), 87-97. doi: $10.1080 / 09603100601018864$

Dewatripont, M., Legros, P., \& Matthews, S. A. (2003). Moral hazard and capital structure dynamics. Journal of European Economic Association, 1(4), 890-930. doi: 10.1162/154247603322493186

Dogra, B., \& Gupta, S. (2009). An empirical study on capital structure of SMEs in Punjab. The IUP Journal of Applied Finance, 15(3), 60-80.

Fluck, Z., Holtz-Eakin, D., \& Rosen, H. S. (2000). Where does the money come from? The financing of small entrepreneurial enterprises [Working Paper $n^{\circ}$ FIN-98-038]. New York University, New York, NY, USA.

Fosberg, R. H. (2004). Agency problems and debt financing: leadership structure effects. Corporate Governance: International Journal of Business in Society, 4(1), 31-38. doi: $10.1108 / 14720700410521943$

Frank, M. Z., \& Goyal, V. K. (2003). Testing the pecking order theory of capital structure. Journal of Financial Economics, 67(2), 217-248. doi: 10.1016/S0304-405X(02)00252-0

Frank, M. Z., \& Goyal, V. K. (2008). Tradeoff and pecking order theories of debt. In E. Eckbo (Ed.), The handbook of empirical corporate finance (Vol. 2, pp. 135-202). Amsterdam: Elsevier Science.

Gartner, W. B., Shaver, K. G., Carter, N. M., \& Reynolds, P. D. (2004). Handbook of entrepreneurial dynamics - the process of business creation. London: Sage Publications.

Gaud, P., Jani, E., Hoesli, M., \& Bender, A. (2005). The capital structure of Swiss companies: an empirical analysis using dynamic panel data. European Financial Management, 11(1), 51-69. doi: 10.1111/j.1354-7798.2005.00275.x

Hall, G. C., Hutchinson, P. J., \& Michaelas, N. (2004). Determinants of the capital structures of European SMEs. Journal of Business Finance \& Accounting, 31(5/6), 711-728. doi: 10.1111/j.0306-686X.2004.00554.x

Harris, M., \& Raviv, A. (1991). The theory of capital structure. The Journal of Finance, 46(1), 297355. doi: 10.1111/j.1540-6261.1991.tb03753.x

Homaifar, G., Zietz, J., \& Benkato, O. (1994). An empirical model of capital structure: some new evidence. Journal of Business Finance and Accounting, 21(1), 1-14. doi: 10.1111/j.14685957.1994.tb00302.x

Jensen, M. C., \& Meckling, W. H. (1976). Theory of the firm: managerial behavior, agency costs and ownership structure. Journal of Financial Economics, 3(4), 305-360. doi: 10.1016/0304405X(76)90026-X 
Jordan, J., Lowe, J., \& Taylor, P. (1998). Strategy and financial policy in UK small firms. Journal of Business Finance and Accounting, 25(1/2), 1-27. doi: 10.1111/1468-5957.00176

Kremp, E., Sauvé, A., \& Paranque, B. (1999). Corporate finance in Germany and France. Banque de France Bulletin Digest, (70), 19-41.

Kremp, E., Stöss, E., \& Gerdesmeier, D. (1999). Estimation of a debt function: evidence from French and German firm panel data. In A. Sauvé \& M. Sheuer (Eds.), Corporate finance in Germany and France - a joint research project of the deutsche Bundesbank and the banque de France (pp. 140-194). Frankfurt am Main: Deutsche Bundesbank and Paris: Banque de France.

Leland, H., \& Pyle, D. (1977). Informational asymmetries, financial structure and financial intermediation. Journal of Finance, 32(2), 371-387. doi: 10.1111/j.1540-6261.1977.tb03277.x

Lemmon, M. L., \& Zender, J. F. (2010). Debt capacity and tests of capital structure theories. Journal of Financial and Quantitative Analysis, 45(5), 1161-1187. doi: 10.1017/S0022109010000499

Liu, Q., \& Tian, G. G. (2009, December). Leverage ratio and determinants of capital structure in SMEs: evidence from China. Proceedings of the Australasian Finance and Banking Conference, Sydney, Australia, 22.

López-Gracia, J., \& Sogorb-Mira, F. (2008). Testing trade-off and pecking order theories financing SMEs. Small Business Economics, 31(2), 117-136. doi: 10.1007/s11187-007-9088-4

Machado, M. A. V., Temoche, C. A. R., \& Machado, M. R. (2004, setembro). Determinantes de estrutura de capital nas pequenas e médias empresas industriais da cidade de João Pessoa/PB. Anais do Encontro Nacional da Associação Nacional de Pós-Graduação e Pesquisa em Administração, Curitiba, PR, Brasil, 28.

Martin, D. L., Nakamura, W. T., Forte, D., Carvalho, A. F., Filho, Costa, A. C. F., \& Amaral, A. C. (2005, julho). Determinantes de estrutura de capital no mercado brasileiro - análise de regressão com painel de dados no período 1999-2003. Anais do Encontro Brasileiro de Finanças, São Paulo, SP, Brasil, 5.

Michaelas, N., Chittenden, F., \& Poutziouris, P. (1999). Financial policy and capital structure choice in U.K. SMEs: empirical evidence from company panel data. Small Business Economics, 12(2), 113-130. doi: 10.1023/A:1008010724051

Mishra, C. S., \& McConaughy, D. L. (1999). Founding family control and capital structure: the risk of loss of control and the aversion to debt. Entrepreneurship: Theory and Practice, 23(4), 53-64.

Modigliani, F., \& Miller, M. H. (1958). The cost of capital, corporation finance and the theory of investment. American Economic Review, 48(3), 261-297. doi: 10.2307/1809766

Myers, S. C., \& Majluf, N. S. (1984). Corporate financing and investment decisions when firms have information that investors do not have. Journal of Financial Economics, 13(2), 187-221. doi: $10.1016 / 0304-405 \mathrm{X}(84) 90023-0$

Nakamura, W. T., \& Jucá, M. N. (2005). A estrutura de capital das empresas de médio porte no Brasil: um estudo empírico. São Paulo: Alinea Editora.

Nguyen, T. D. K., \& Ramachandran, N. (2006). Capital structure in small and medium-sized enterprises: the case of Vietnam. ASEAN Economic Bulletin, 23(2), 192-211. doi: 10.1353/ase.2007.0006

Omer, T. C., \& Terando, W. D. (1999). The effect of risk and tax differences on corporate and limited partnership capital structure. National Tax Journal, 52(4), 699-716. 
Ozkan, A. (2001). Determinants of capital structure and adjustment to long run target: evidence from UK company panel data. Journal of Business Finance \& Accounting, 28(1/2), 175-198. doi: $10.1111 / 1468-5957.00370$

Oztekin, O., \& Flannery, M. J. (2012). Institutional determinants of capital structure adjustment speeds. Journal of Financial Economics, 103(1), 88-112. doi: 10.1016/j.jfineco.2011.08.014

Perobelli, F. F. C., \& Famá, R. (2001, julho). Fatores determinantes da estrutura de capital: aplicação a empresas de capital aberto no Brasil. Anais do Encontro Brasileiro de Finanças, São Paulo, SP, Brasil, 1.

Petersen, M., \& Rajan, R. (1994). The benefits of lending relationships: evidence from small business data. Journal of Finance, 49(1), 3-37. doi: 10.1111/j.1540-6261.1994.tb04418.x

Rajan, R. G., \& Zingales, L. (1995). What do we know about capital structure? Some evidence from international data. Journal of Finance, 50(5), 1421-1460. doi: 10.1111/j.15406261.1995.tb05184.x

Sanchez-Vidal, J., \& Martin-Ugedo, J. F. (2005). Financing preferences of Spanish firms: evidence on the pecking order theory. Review of Quantitative Finance and Accounting, 25(4), 341-355. doi: 10.1007/s11156-005-5459-6

Shyam-Sunder, L., \& Myers, S. C. (1999). Testing static tradeoff against pecking order models of capital structure. Journal of Financial Economics, 51(2), 219-244. doi: 10.1016/S0304405X(98)00051-8

Stiglitz, J., \& Weiss, A. (1981). Credit rationing in markets with imperfect information. American Economic Review, 71(3), 393-410.

Titman, S., \& Wessels, R. (1988). The determinants of capital structure choice. Journal of Finance, 43(1), 1-19. doi: 10.1111/j.1540-6261.1988.tb02585.x

Trovato, G., \& Alfó, M. (2006). Credit rationing and the financial structure of Italian small and medium enterprises. Journal of Aplied Economics, 9(1), 167-184.

Voulgaris, F., Asteriou, D., \& Agiomirgianakis, G. (2004). Size and determinants of capital structure in the Greek manufacturing sector. International Review of Applied Economics, 18(2), 247-262. doi: 10.1080/0269217042000186714

Wald, J. K. (1999). How firm characteristics affect capital structure: an international comparison. Journal of Financial Research, 22(2), 161-187.

Wijst, N. van der, \& Thurik, R. (1993). Determinants of small firm debt ratios: an analysis of retail panel data. Small Business Economics, 5(1), 55-65. doi: 10.1007/BF01539318

Wintoki, M. B., Linck, J. S., \& Netter, J. M. (2012). Endogeneity and the dynamics of internal corporate governance. Journal of Financial Economics, 105(3), 581-606. doi: 10.1016/j.jfineco.2012.03.005

Wu, J., Song, J., \& Zeng, C. (2008). An empirical evidence of small business financing in China. Management Research News, 31(12), 959-975. doi: 10.1108/01409170810920666 